\title{
FAMILY FOCUSED NURSING EDUCATION
}

\author{
R.A.E. Thompson

\begin{abstract}
Paper presented at the annual national conference of the Nursing Education Association held in Cape Town on 27-28 August 1993.
\end{abstract}

\begin{abstract}
At the present time the majority of nurse education programmes are firmly tied to the perspectives of curative medicine within hospitals - they are disease and hospital oriented. This model, which indicates a 'sickness' concept of nursing, is entirely inappropriate if contemporary and future health care needs are to be met. The shift in education should be towards a health, family and whole person centered approach.
\end{abstract}

The family is the most fundamental and dynamic unit in society with a profound influence upon its members. Besides performing a variety of other functions, the family has a central role in promoting and maintaining the health of its members. Because the fomily unit is the microcosm of society and accurately reflects the needs of society at large it is appropriate that this should be a key area of experience. Family attachments during training provide opportunities for close and committed contact with people in their everyday world and for leaming what is really important to them.

This paper describes the experiences within the Department of Nursing at the University of Cape Town following the introduction, in 1984, of an entirely revised under-graduate nursing degree curriculum which is health, whole person and family centred rather than disease centred.

\section{Uittreksel}

Huidig is die meeste verpleegonderwys programme siekte-en hospitaal ge-orienteerd en het dus 'n kuratieve perspektief. Hierdie model, wat 'n "siekte" perspektief van verpleging weergee, is heeltemal onvanpas indien kontemporêre en toekomstige gesondheidshehoeftes bevredig moet word. Ek is oonuig dat die ommeswaai in opvoedkunde behoort te wees in die rigting van gesondheid, die gesin en 'n persoon-gesentreerde benadering.

Die gesin is die mees belangrikste en dinamiese eenheid in die samelewing wat 'n merkbare invloed op sy lede maak. Afgesien van ander funksies, speel die gesin 'n sentrale rol in die bevordering en handhawing van die gesin se gesondheid. Gesinsbetrokkenheid behoort dus 'n belangrike ondervindingsveld vir verpleegkundiges te wees tydens hul opleiding omdat dit geleenthede bied om met mense in hulle alledaagse lewens te verkeer en om van hulle te leer wat vir hulle belangrik is.

Hierdie verhandeling beskryf die ondervindinge in die Departement Verpleegkunde te Universiteit van Kaapstad, na die instelling in 1984 van ' $n$ alegehele hersiende kurrikulum vir die ondengraadse verpleegonderwysprogram wat sentreer rondom gesondheid, die hele persoon en die gesin in plaas van "siektes".

The first World Congress on the Family in 1992 and the United Nations declaration of 1994 as the Year of the Family bears testimony to the collective concern for the family as an instituition and indeed the recognition of the family unit as pivotal to individual and societal integrity, health and stability. With the signs of family disintegration confronting us daily both as citizens and as nurses, the need to turn the tide and to work for restoration and reconciliation cannot be disputed.

If our premise is the centrality of the family in society, and I believe it is fair to assume it is, then questions we must ask are - how do we enable future health professionals and particularly nurses to learn about the family, to learn about effective family functioning, to learn about the families' roles in society and family strengths... to name but a few key areas?

In tackling this problem the following issues need to be addressed:-

1. Do our nursing curricula reflect this emphasis on the family or is the family merely one of many topics which form a part of the curriculum?

2. How do we enable students to come to terms with their own experiences of family or indeed lack of such experiences - to deal with their own humanity (their strengths and their weaknesses), to understand their own values, culture and behaviour patterns; to learn how a family functions effectively?

3. How do we enable students to develop the attitudes and skills that will assist them to work with individuals and families to enhance their quality of life and the therapeutic potential of family members? (Families usually are the main carers.)

This requires that we enable students to develop relational skills and to learn about building healthy families. This is difficult to do if their experience of family is confined to their own family only.

These are not just academic questions, but issues with which we, as nurse 
educators must wrestle if we (and our students) are to contribute to the rebuilding of the lives and homes of their patients which lie in ruins.

Within the Department of Nursing at the University of Cape Town, an entirely revised under-graduate nursing degree curriculum was introduced in 1984 , one which is centred on health, the whole person and the family rather than on disease. It focuses on families and communities becoming autonomous in identifying and meeting their own health needs.

Because the family unit is the microcosm of society and accurately reflects the needs of society at large it is appropriate that this should be a primary area of experience in the education of all health care professionals and indeed of all other caring professionals too.

I believe that the family is the most fundamental and dynamic unit in society with a profound influence upon its members. It performs a variety of key functions and has a central role in promoting and maintaining the health of its members. I am not an expert on the family - but I believe deeply that the family is created as the ideal unit in which husband and wife develop a satisfying and enriching relationship, and to whom children are born and grow and develop to their maximum potential.

If nursing is to address not only the current health needs but also those of the future then students nurses must, from the outset, be in close and committed contact with people in their everyday world.

As our new curriculum is health rather than sickness orientated, and aims to address the needs of persons at each stage of the lifespan, and to do so within the context of the family and community to which the person belongs, it was natural in the new structure that the family should be the focal area of attention. Being attached to and involved with a selected family during training provides opportunities for the students for learning what is really important to people. Students come to see through the eyes of the public the health needs of the members of the family and the health care services provided for these needs. Given this opportunity students see from the beginning the importance of the public's role in and their perspective on their health care and also their involvement in decision making processes.
Throughout the four year baccalaureate programme the content of each year of study is based on a specific period of the life span and the family and community learning opportunities are appropriately arranged. In their first year our students commence their first clinical practicum with a carefully selected well-functioning family just 4 weeks after their commencement of the programme. Each student is allocated to a family whom they visit, at least weekly, over a 6 week period with specific objectives to achieve.

The main aim of such family study is to contribute to the students' understanding of family dynamics in relation to health and to do so within the context of personal relationships. The effect of the community on the health of the family (and vice versa) is also emphasised.

Students visit their families on their own without the presence of a mentor to enable them to learn from the pubhc and to work with (rather than doing things for) the members of the community. Starting their experience in the home setting emphasises the centrality of the family in society and specifically in health care, and also provides the milieu in which key attitudes and skills are fostered. These include listening, establishing, maintaining and terminating relationships, valuing and learning from other's perspectives, understanding differences in the effects of culture, learning that there is no one right way! ...etc. Within this family context they have to develop their own relationships and work through any difficulties which may occur. In the home setting it is more difficult to avoid issues than in the impersonal setting of the hospital or clinic.

The family study provides the opportunity to look at family health practices and health status, and to develop a more comprehensive understanding of these health practices and their influence on both the community and the family's health status.

Weekly tutorials are held at which experiences are shared and issues of concern are addressed and weekly reports are submitted. The tutorials enable students to benefit from one another's experiences and insights while gaining a new awareness of the meaning of their own experiences of the richness and variety of family living. In addition, because of the commitment which develops between the student and the family, knowledge is often more readily internalised and applied.

The family attachment allows the student to develop at his/her own pace unlike the hospital setting where they are forced to adopt the pace, for example, of an acute ward where such hospital experience often skews personal growth, and even may inhibit it.

Later in their first year students undertake a second study visiting in his/her home an elderly patient whom they have nursed in a hospital ward. In this way the impact of illness on the family is highlighted and the necessary adjustments to daily living activities become clearly evident.

The development of the student's awareness of the family as the complete human unit, and not as an isolated 'unit' in the hospital bed permits the relevance of the family unit in the treatment of the patient to become a foundational principle for the students future professional practice.

Alongside the hospital experience in each of the subsequent three years, students are involved in family studies with objectives relating to the period of the lifespan under study. Family studies involving adults with chronic conditions, disabled persons and adults recently sent home from hospital form the content of the second year studies. These are also complemented with experience in related suppport organisations.

In their third year students are involved with child health and their formal study in this sphere is implemented through experience of a family with a toddler/pre-school aged child with a mother who is $\mathbf{8}$ months pregnant at the start of the practicum. This family study spans a period of 6 months and covers part of the second semester when the midwifery component of womens' health is the focus.

In fourth year the family study involves a family in which there is a member who is mentally ill or handicapped who is living in the home.

Within each of the four years the issues within the families become more challenging as students are exposed to families with social or economic problems and families which may be dysfunctional for a variety of reasons. Students are thus enabled to work with individuals and families within the community in a variety of settings and to 
respond to their needs in a manner appropriate to the specific person/family/group. The attitudes, knowledge and skills that are developed within this practical setting are central to achieving effective and appropriate care and in forging community partnerships in health care.

Considerable care is taken in selecting families but unless there is a specific need to do so, staff do not visit the family with the student. Students visit alone or occasionally in pairs if the study has been so organised. This aspect, while involving a measure of risk, is basic to the success of the approach as the dynamic is altered when professional staff are present, although the student is encouraged to be present when the family is being visited by a community nurse or social worker. Nevertheless staff are readily available to students (telephonically and in person) and carefully planned weekly tutorials are held.

The curriculum is constructed so that the knowledge and skills students require (eg interpersonal skills) are taught at appropriate stages. Assignments and formal evaluations require the student to demonstrate the attitudes, knowledge \& skills acquired within a specific context. In so doing there is a cohesiveness and integration (holism) throughout the programme.

\section{RATIONALE FOR RECONSTRUCTED PROGRAMME DESIGN}

The Department of Nursing at UCT embarked on this journey because we believed in the fundamental relevance of the family to the practice of nursing. We believed, too, that the context in which learning takes place is critical and we therefore endeavoured to create the potential for maximum relevance of the programme material. We could not forsee how dynamic it would turn out to be nor the extent of the very powerful impact on both staff and students. These we have come to appreciate with hindsight!

In the past, nurse educators appear to have underestimated the value and the potential for meaningful optimal learning which practical experience can offer. In many programmes scant attention has been paid to the nature of the context in which attitudes and requisite inter-personal skills are best acquired.

Previously the hospital has been the almost exclusive environment for application of academic and clinical knowledge. My concern is that the student must develop her potential as a human being and as a professional person, and the context of learning must facilitate this. Therefore it is essential that we develop concepts of education in which students gain carefully timed and graded experience in exploring and exercising their own humanness in the series of human encounters which constitute their professional programme. Since clinical practice takes place in the framework of human relationships, the development of the ability to relate to others satisfactorily is obviously of primary importance. Therefore it is essential that professional preparation provides the student with tools for understanding and adapting her own behaviour to the needs of his/her patients/clients. It must also provide situations in which students may experiment with new behaviour. [Ward and Webster 1965:103-6]

As the students original behavioural patterns and attitudes usually have been moulded in the context of the family, it is appropriately consequential that insights into and adjustments to such behaviour could best take place within a family setting.

For any health care professional it is important to recognise that if the hospital is seen as the pivotal unit, it becomes the primary focus and everything else is peripheral. If the home (family) is presented as the pivotal unit, then hospital treatment is seen as a means of returning the person to the pivotal unit in society rather than as an end in itself. I believe we are seeing the need to work with man as a whole person as an individual in his society. The hospital must (and I am sure always will be) an area in which nurses \& other health care professionals are educated, but its role as the major (and in some countries exclusive) sphere of clinical experience should not continue. Both social and economic pressures require a less intense and more appropriate means of providing suitable health care.

\section{THE OUTCOME OF THE RECONSTRUCTED PROGRAMME DESIGN}

The results of our change in focus, while still in the process of being evaluated, are most apparent in the changed attitudes, depth of insight and understanding, and the overall personal \& professional growth evident in the students at a level which indeed has exceeded our expectations.
Many of the first year student's comments mostly made just 12 weeks after commencing the programme speak for themselves. The comments can be grouped into overall insights gains:

\section{Family structure and function:}

The vast number of skills required for life in a family tend to go unrecognised. This study has helped to point them out so I can thank my parents.

By looking at other families, I could identify the strengths and weaknesses within my own family and I have also leamt to appreciate what I have while I still have it.

It has become obvious that if one person is not functioning optimally it really does affect the rest of the family.

I never wanted to get married because of what I experienced with my parents, marriage was not something to consider. I want to have children but not a husband. Now I see that marriage can be fulfilling and something wonderful... something $I$ never knew it could be.

This study gave me an insight which was new to me coming from a divorced family.

I didn't realise it took so much co-operation from each member of the family to form a close knit unit.

\section{Parenting:}

$I$ realised just how all-consuming childraising can be, understanding the tiredness and frustration mothers must feel. Understanding how demanding children are physically, emotionally and mentally.

I leamt that I've always taken my mother for granted. Until now I didn't realise how much work goes into being a mother.

Children are something that must be planned! (from a student who was in a family with one year old quadruplets!!)

\section{Learning about self:}

Ilearnt lots of things not only about the family but also about myself.

I have leamt how valuable human relationships are and how important it is to have interaction with others. 
4. Families of other cultures:

It has helped me to gain confidence in myself to meet new and foreign people and be able to accept them for what they are and allow them to accept me.

It has shown me how different people fulfill their needs.

I have learnt to be objective and non-judgemental until I have all the facts.

\section{The family study experience:}

Overall I've learned and grown a lot through this study. It hasn't always been the most pleasant or enjoyable experience - but has always been worthwhile. If it were discontinued it would be to deprive others of the opportunity of a lifetime.

Through this family study I have grown and leamt more than I could ever have expected to.

The trust I have experienced also helped me to share myself and to reveal my feelings and needs - this is a real milestone for me because previously I was unable to do so.

I've become more perceptive, not only of others' feelings but also of my own. I'm now able to understand why I sometimes feel the way I do. Can also pick up others feelings more quickly and accurately. I'm more able to say what I feel and think, don't bottle everything up anymore.

One of the most important things I have learnt this year is to truly accept and love people for who they are.

When I think of how I've grown this year it's almost overwhelming because Ifeel almost as though the person who started the course at the beginning of the year is a complete stranger to me now. For the first time in my life I have got to the end of a year and I really feel as though I have achieved something worthwhile. I have never felt so fulfilled and happy to be the person that I am before. It's great to be alive.

These rewarding observations confirm for us the benefits gained by the students but, what has this approach meant for the staff?

It has provided a profound awareness of the fundamental essence of successful teaching and learning.
Virkler [1988] identifies four approaches and states that in teaching one can:

a) share one's life with teaching in it;

b) share teaching with one's life in it;

c) teach with no personal life in it;

d) share one's life with no teaching in it.

The first is the approach we have taken in the Department, to share with our students our experiences of life and to allow them to share theirs and then to relate these to the relevant theoretical issues (ie sharing our lives with teaching in the sharing.)

In this way one is dealing with the everyday reality of life and human experience and interpreting this from appropriate theoretical foundations. In so doing, learning and teaching have a significance and dynamic which is not possible otherwise.

Virkler [1988:28-32] goes on to say .. The natural outgrowth of living life rather than living a system of ideas is that one will eventually teach life rather than a system of ideas therefore one's teaching style continues to be altered by one's lifestyle. The freer one is to live life, the freer one is to teach life. Real life, full life, continuous life, at all times and in all situations. The goal is to share one's life with teaching flowing within. Enough cognitive information needs to be clearly communicated either before or within the story to provide a solid reference point to begin with. The most effective classes will be those which flow out of the stories of life. As these are told classroom discussion itself becomes a drama/story, as a theme comes alive under the skillful leadership of the teacher.

For the teacher this presents considerable risk taking for one does not have control over the stories of life which students share. It requires a willingness to be vulnerable, to share oneself - for one is tested not only as an academic and professional practitioner but also as a person. The rewards however, repeatedly have far outweighed these risks.

To return to my opening question... How do we enable future health professionals and particularly nurses to learn about the family?

Risky, threatening to both the students and staff though this experience has been, in the words of one of the students "it's been the opportunity of a lifetime.."

What is more, and this is the really exciting thing, every year with new students and new families, new insights abound and I know we have been led to a goldmine!

\section{REFERENCES}

SKEET, M \& THOMPSON, R. (1985). Creative Nursing: processive care \& more? Inl of Advanced Nursing. 10,15-24.

THOMPSON, R. (1986). Today's nursing for tomorrow's health. Curationis. 9,4,1-8 \& 18.

THOMPSON, R. (1990). Theoretical underpinnings in Community based primary care in developing countries. Current Issues in Nursing. 3rd ed. McCloskey, J \& Grace, $\mathbf{H}$.

VIRKLER, M \& P. (1988). Transmitting spirit life in the classroom. 28-32. New York: Communion with God Publishers.

WARD, L.M. \& WEBSTER, E.J. (1965). The training of clinical personnel. 1: Issues of conceptualsation. Asha 7,38-40.

WARD, L.M. \& WEBSTER, E.J. (1965). The training of clinical personnel. 2: A concept of clinical preparation. Asha 7,103-106.

WHO. (1991). The nursing in action project. Health for All series, no.3. Copenhagen, WHO, 17-20.

\section{ACKNOWLEDGEMENT}

Mrs Una Kyriacos for the translation of the abstract.

ROSALIE A.E. THOMPSON

M Pub Adm, RN, RM, DNEd

Professor: Head Department of Nursing University of Cape Town 